\title{
Evaluation of Impedance Measurements on Al-Pure Corrosion in 1.0 M HCl in the Presence of Organic Schiff
}

\author{
A.S. Patel, V.A. Panchal, P.T. Trivedi and N.K. Shah ${ }^{*}$ \\ Department of Chemistry, School of Sciences, Gujarat University, \\ Ahmedabad-09, Gujarat, India
}

Received 13 May 2011; accepted 30 June 2012

\begin{abstract}
The inhibition performance of two Schiff bases, namely (A) Benzenamine, 2-chloro-N[(4-methoxyphenyl)methylene] and (B) Benzenamine, 3-chloro-N-[(4methoxyphenyl)methy-lene] as corrosion inhibitors for Al-Pure in $1.0 \mathrm{M} \mathrm{HCl}$ has been investigated by galvanostatic polarization measurement, electrochemical impedance spectroscopy (EIS) and weight loss method. Galvanostatic polarization study showed that two inhibitors are mixed type with predominant action on the cathode. The adsorption of inhibitors on Al-Pure surface was found to follow Langmuir adsorption isotherm and the thermodynamic parameters $\left(\mathrm{E}_{\mathrm{a}}, \Delta \mathrm{G}_{\mathrm{ads}}\right.$ and $\left.\mathrm{Q}_{\mathrm{ads}}\right)$ were determined. Two Schiff bases have shown remarkable inhibition on the corrosion of Al-Pure in $1.0 \mathrm{M}$ $\mathrm{HCl}$ solution. The high inhibition efficiency was attributed to the blocking of active sites by adsorption of inhibitor molecules on the metal surface.
\end{abstract}

Keywords: Al-Pure, Schiff bases, Inhibition efficiency, EIS.

\section{Introduction}

Corrosion is defined as the deterioration of the material, usually a metal, because of reaction with its environment and which requires the presence of an anode, a cathode, an electrolyte and an electrical circuit [1].

Acid solutions are generally used for the pickling, industrial acid cleaning, acid descaling, oil well acidizing, etc. [2-5]. Al-Pure and its alloys are important materials due to their high technological value and wide range of industrial applications, especially in aerospace, household industries, and commonly used in marine applications as well. In addition, they are justified by low price, high electrical capacity and high energy density [6].

Because of widely used in many industrial processes, aluminium and its alloys could be corroded during these acidic applications particularly with the use of

\footnotetext{
*Corresponding author. E-mail: nishchem2004@yahoo.co.in
} 
hydrochloric acid and sulphuric acid. Corrosion prevention of metals has always been an important subject to be dealt with. The prevention of corrosion is vital not only for increasing the life-time of equipments, but also for decreasing the dissolution of toxic metals from the components into the environment. The use of organic molecules as corrosion inhibitors is one of the most practical methods for protecting metals against the corrosion and it is becoming increasingly popular. Inhibitors are used to prevent metal dissolution and minimize acid consumption. Most of the efficient acid inhibitors are organic compounds that contain mainly nitrogen, sulphur or oxygen atoms in their structure. Despite the large number of organic compounds, there is always a need for developing new organic corrosion inhibitors [7-9].

Recently, Schiff base compounds have been of interest in order to obtain efficient corrosion inhibitors since they provide much greater inhibition by adsorption on metal surface compared with corresponding amines and aldehydes [10-17]. Some Schiff bases have recently reported as effective corrosion inhibitors for steel [18, 19], aluminium [20], aluminium alloys [21, 22] and copper [23] in acidic media. The presence of $-\mathrm{C}=\mathrm{N}$ - group in Schiff base molecules enhances their adsorption ability and corrosion inhibition efficiency [24, 25]. The action of such inhibitors depends on the specific interaction between the functional groups and the metal surface. So it is very important to clarify the interactions between the inhibitor molecules and metal surfaces in order to search new and efficient corrosion inhibitors [26].

In earlier work the inhibition of corrosion of zinc in sulphuric acid and aluminium in hydrochloric acid by Schiff bases of ethylenediamine [27], orthosubstituted aniline-N-salicylidenes [28], ortho-, meta-, and para- aminophenol-Nsalicylidenes [29], meta-substituted aniline-N-salicylidenes [30], salicylidine$\mathrm{N}, \mathrm{N}^{\prime}$-dimorpholine [31] and aniline-N-benzylidene [32] has been reported.

In the present work, the inhibitive effectiveness of (A) and (B) Schiff bases have been studied in retarding corrosion of Al-Pure in $1.0 \mathrm{M} \mathrm{HCl}$. Galvanostatic polarization, electrochemical impedance spectroscopy (EIS) and weight loss method were used to investigate the inhibiting influence of (A) and (B). Both inhibitors are substitutants of chloroaniline-N-(p-methoxy benzylidene). So comparatively both inhibitors give very similar results with negligible differences.

\section{Experimental}

\section{Synthesis of Schiff bases}

The Schiff bases used in the present work were synthesized from equimolar amounts of p-methoxy benzaldehyde and corresponding amines (o-chloroaniline and m-chloroaniline) through a condensation reaction in ethanol media as method described by Shah et al. [33]. All the used chemicals for preparation of Schiff bases were AR grade (MERCK). The compounds were characterized through their structure data [IR data (Fig.1)] and their purity was confirmed by thin-layer chromatography (TLC). The chemical structures of the investigated compounds are given below: 


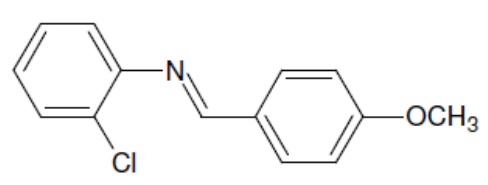

(A)

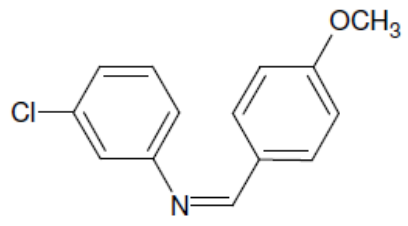

(B)

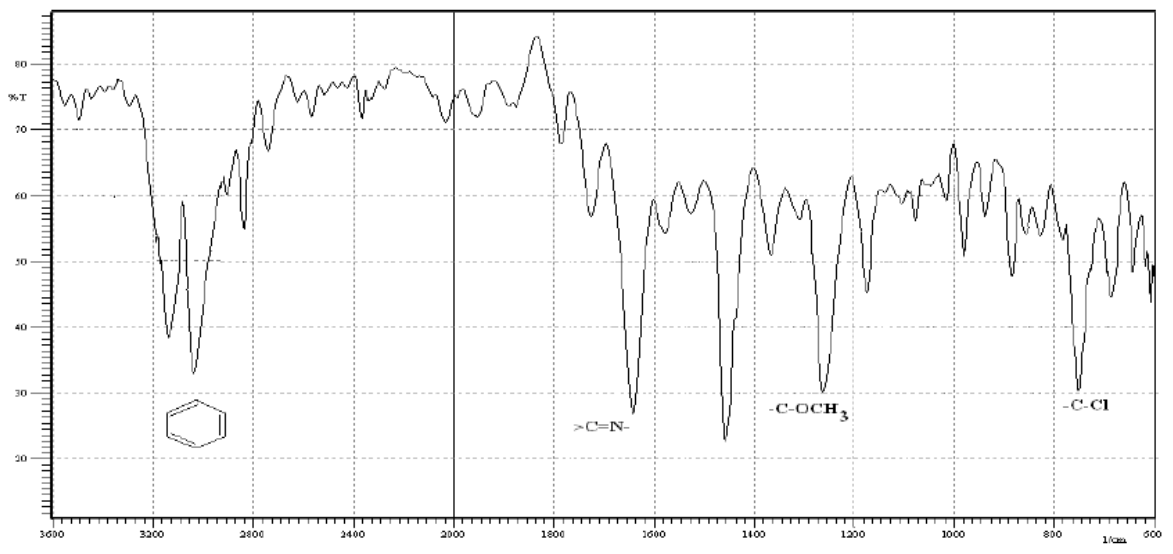

o-chloroaniline-N-(p-methoxy benzylidene) (A)

aromatic ring :- $3130 \mathrm{~nm},>\mathrm{C}=\mathrm{N}-$ :- $1642 \mathrm{~nm},-\mathrm{C}-\mathrm{OCH}_{3}$ :- $1263 \mathrm{~nm},-\mathrm{C}-\mathrm{Cl}$ :- $754 \mathrm{~nm}$

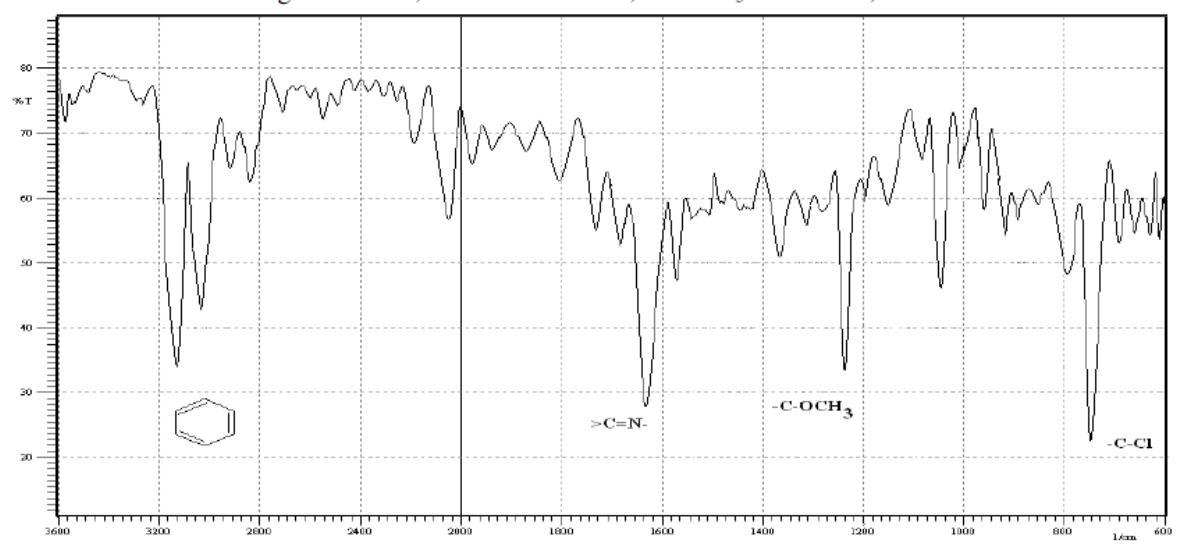

m-chloroaniline-N-(p-methoxy benzylidene) (B)

aromatic ring :- $3165 \mathrm{~nm},>\mathrm{C}=\mathrm{N}-:-1634 \mathrm{~nm},-\mathrm{C}-\mathrm{OCH}_{3}$ :- $1242 \mathrm{~nm},-\mathrm{C}-\mathrm{Cl}$ :- $737 \mathrm{~nm}$

Figure 1. IR spectra of compounds (A) and (B).

\section{Electrodes and electrolytes}

99.9\% pure aluminium was used in this study. Rectangular specimens of Al-Pure of size $6 \mathrm{~cm} \times 3 \mathrm{~cm}$ and thickness $0.050 \mathrm{~cm}$ with a small hole of about $2 \mathrm{~mm}$ diameter just near the upper end of the specimen were used for the determination of weight losses. The specimens were polished with ' 0 ', ' 00 ', '000' and ' 0000 ' grade emery paper. The specimens degreased by A. R. carbon tetrachloride (sulphur free).

For polarization and impedance measurements, metal coupons of circular design, diameter $2.802 \mathrm{~cm}$ with a handle $3 \mathrm{~cm}$ long and $0.5 \mathrm{~cm}$ wide and thickness 0.050 $\mathrm{cm}$ with a small hole of about $2 \mathrm{~mm}$ diameter just near the upper end of the specimen were used. The handle and the back of the coupon and of the auxiliary platinum electrode were coated with Perspex leaving only the circular portion of the specimen of apparent surface area $6.156 \mathrm{~cm}^{2}$ exposed to the solution. 
The corrosive solution $(1.0 \mathrm{M} \mathrm{HCl})$ was prepared by dilution of analytical grade $37 \% \mathrm{HCl}$ (NICE) with double distilled water. The concentration range of employed inhibitors was 0.001 to $0.5 \%$ in $1.0 \mathrm{M} \mathrm{HCl}$. The concentration range of employed inhibitor was 0.001 to $0.5 \%$ in $1.0 \mathrm{M} \mathrm{HCl}$.

\section{Measurements}

Three methods, namely polarization study, impedance spectroscopy and weight loss method, were used to determine the corrosion inhibition efficiencies of Schiff bases.

\section{Electrochemical measurements}

Electrochemical experiments were carried out using a standard electrochemical three-electrode cell. Al-Pure was used as working electrode, platinum as counter electrode and saturated calomel electrode (SCE) as reference electrode. The test solution was contained in a H-type $(80 \mathrm{~mL}$ in each limb) Pyrex glass cell with Luggin capillary as near to the electrode surface as possible, and a porous partition to separate the two compartments. The potential was measured against a saturated calomel electrode (SCE), in polarization study.

Corrosion parameters such as corrosion potential $\left(\mathrm{E}_{\mathrm{corr}}\right)$, corrosion current density $\left(\mathrm{I}_{\text {corr }}\right)$ and Tafel plots were measured in polarization method. In this study, the current density was varied in the range of $2 \times 10^{-4}$ to $3.25 \times 10^{-2} \mathrm{~A} \mathrm{~cm}^{-2}$. The inhibition efficiencies at different inhibitor concentrations are calculated using the following equation:

$$
\text { Inhibition efficiency }(\% \mathrm{IE})=\frac{\mathrm{I}^{\mathrm{o}} \text { corr }-\mathrm{Icorr}}{\mathrm{I}^{\mathrm{o}} \text { corr }} \times 100
$$

where, $\mathbf{I}_{\text {corr }}^{\mathbf{o}}$ and $\mathrm{I}_{\text {corr }}$ are the corrosion current densities in the absence and presence of the inhibitors, respectively.

Electrochemical impedance measurements were carried out in the frequency range of $20 \mathrm{kHz}-0.1 \mathrm{~Hz}$ at the open circuit potential with applying amplitude of $5 \mathrm{mV}$ ac signal (AUTOLAB). Double layer capacitance $\left(\mathrm{C}_{\mathrm{dl}}\right)$ and charge transfer resistance $\left(R_{c t}\right)$ values were calculated from Nyquist plots as described by Hosseini [34]. EIS data were analyzed using frequency response analyzer (FRA) electrochemical setup. The inhibition efficiencies at different inhibitor concentrations were calculated using the following equation:

$$
\text { Inhibition efficiency }(\% \mathrm{IE})=\frac{\mathrm{R} c t-\mathrm{R}^{\mathrm{o}} c t}{\mathrm{R} c t} \times 100
$$

where, $\mathrm{R}_{\mathrm{ct}}$ and $\mathrm{R}_{\mathrm{ct}}^{\mathrm{o}}$ are the charge transfer resistance of the electrode with and without the inhibitors, respectively.

\section{Weight loss (chemical) method}

In weight loss method, the specimens were exposed to $1.0 \mathrm{M} \mathrm{HCl}$ solutions containing controlled additions of two Schiff bases in the range $0.001 \%$ to $0.5 \%$ inhibitor concentration. One specimen only was suspended by a glass hook in each beaker containing $230 \mathrm{~mL}$ of the test solution which was open to the air at $35 \pm 0.5{ }^{\circ} \mathrm{C}$, to the same depth of about $1.5 \mathrm{~cm}$ below the surface of the test 
solution. The experiments were repeated at different temperatures, ranging from $35 \pm 0.5{ }^{\circ} \mathrm{C}$ to $65 \pm 0.5{ }^{\circ} \mathrm{C}$ in the absence and presence of $0.5 \%$ inhibitor's concentration after 60 minutes.

The percentage inhibition efficiency (\%IE) and surface coverage $(\theta)$ were calculated using the following equations:

$$
\begin{aligned}
\text { Inhibition efficiency }(\% \mathrm{IE}) & =\frac{W_{u}-W_{i}}{W_{u}} \times 100 \\
\text { Surface coverage }(\theta) & =\frac{W_{u}-W_{i}}{W_{u}}
\end{aligned}
$$

where, $\mathrm{W}_{\mathrm{u}}=$ weight loss of Al-Pure in uninhibited acid and $\mathrm{W}_{\mathrm{i}}=$ weight loss of Al-Pure in inhibited acid, respectively.

\section{Results and discussion \\ Polarization study}

The galvanostatic polarization curves of $\mathrm{Al}-\mathrm{Pure}$ in $1.0 \mathrm{M} \mathrm{HCl}$ in the presence and absence of two different concentrations of (A) and (B) inhibitors are shown in Fig. 2. From the figure, it is observed that in the presence of (A) and (B) inhibitors, both of the cathodic and the anodic curves show lowest current density than those observed in the uninhibited solution [without the inhibitors]. This behavior indicated that the two Schiff bases have effect on both cathodic and anodic reactions of corrosion process. Therefore, these Schiff bases could be classified as mixed type inhibitors at lower inhibitor concentration. Both the inhibitors shift the potential in the negative direction; this effect is more evident at higher concentrations, which means that the inhibitors affect cathodic reaction more than anodic reaction. The values of cathodic Tafel slope $\left(b_{c}\right)$ and anodic Tafel slope $\left(b_{a}\right)$, calculated from the linear region of the polarization curves, are given in Table 1. The corrosion current density $\left(\mathrm{I}_{\text {corr }}\right)$ was determined from the intersection of the linear parts of the cathodic curves with stationary corrosion potential $\left(\mathrm{E}_{\mathrm{corr}}\right)$.

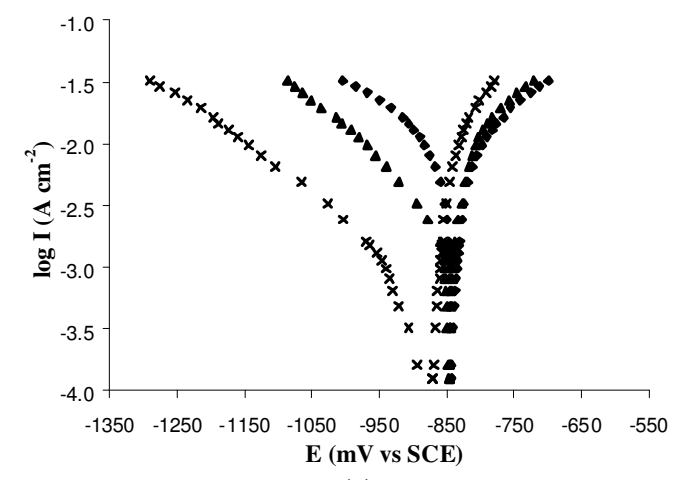

(a)

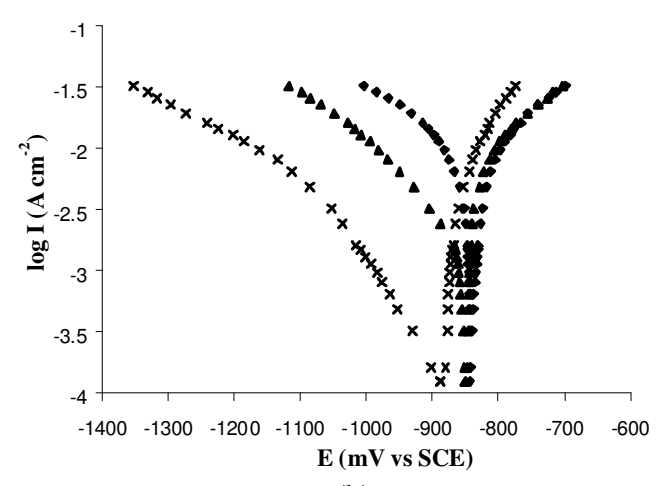

(b)

Figure 2. Anodic and cathodic polarization curves obtained for Al-Pure metal at $35 \pm$ $0.5{ }^{\circ} \mathrm{C}$ in $1.0 \mathrm{M} \mathrm{HCl}$ in various concentrations of the studied Schiff bases. (a) Compound A, (b) Compound B. 
The Tafel parameters and inhibition efficiencies (\%IE) calculated from the polarization data are given in Table-1. The inhibition efficiencies obtained by extrapolation of the cathodic Tafel line to the corrosion potential agree well with those calculated from weight loss data. This suggests that in presence of the inhibitors, both the cathode and the anode are polarized, but the cathode is polarized to a greater extent at higher inhibitor concentration. The inhibitors thus appear to be mixed type inhibitors with predominant action on the cathode.

Table 1. Electrochemical parameters of corrosion of Al-Pure in the presence of different concentrations of the inhibitors at $35 \pm 0.5{ }^{\circ} \mathrm{C}$ and corresponding inhibition efficiencies obtained from polarization method.

\begin{tabular}{ccccccc}
\hline Inhibitor & $\begin{array}{c}\text { Concentration } \\
(\% \mathrm{~V} / \mathrm{V})\end{array}$ & $\begin{array}{c}\mathrm{E}_{\text {corr }} \\
(\mathrm{mV})\end{array}$ & $\begin{array}{c}\mathrm{b}_{\mathrm{a}} \\
(\mathrm{mV} / \mathrm{dec})\end{array}$ & $\begin{array}{c}\mathrm{b}_{\mathrm{c}} \\
(\mathrm{mV} / \mathrm{dec})\end{array}$ & $\begin{array}{c}\mathrm{I}_{\text {corr }} \text { for } \\
\text { cathodic }\left(\mathrm{A} \mathrm{cm}^{-2}\right)\end{array}$ & $(\% \mathrm{IE})$ \\
\hline Blank & - & -843 & 113 & 120 & $4.467 \times 10^{-3}$ & - \\
(A) & 0.001 & -846 & 81 & 133 & $1.412 \times 10^{-3}$ & 68.4 \\
& 0.05 & -870 & 74 & 168 & $4.168 \times 10^{-4}$ & 90.7 \\
(B) & 0.001 & -851 & 81 & 122 & $1.230 \times 10^{-3}$ & 72.5 \\
& 0.05 & -887 & 86 & 173 & $3.630 \times 10^{-4}$ & 91.9 \\
\hline
\end{tabular}

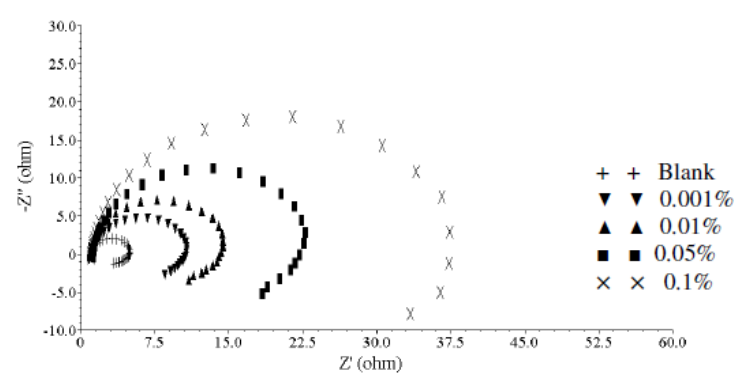

(a)

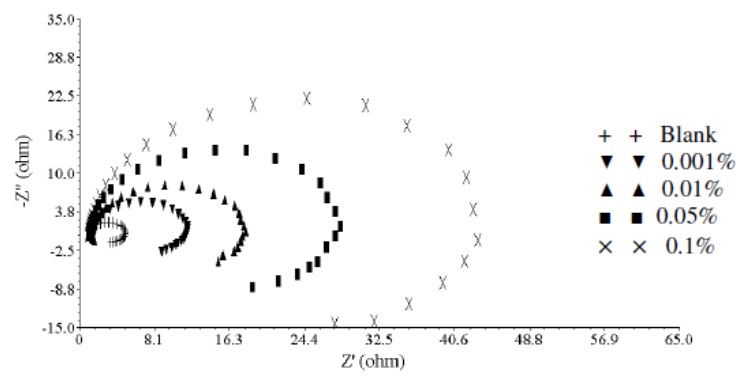

(b)

Figure 3. Impedance plot obtained at $35^{\circ} \mathrm{C}$ in $1.0 \mathrm{M} \mathrm{HCl}$ in various concentrations of Schiff bases: (a) compound A, (b) compound B.

\section{Electrochemical impedance spectroscopy}

Impedance measurements were carried out after immersion of 60 minutes in 1.0 $\mathrm{M} \mathrm{HCl}$ solutions in absence and presence of different concentrations of Schiff bases. The Nyquist plots for various concentrations of Schiff bases (A) and (B) are given in Fig. 3. From the figures, it is clear that the impedance diagrams 
obtain yield a semi-circle shape. This indicates that the corrosion process is mainly controlled by charge transfer.

The equivalent circuit fitting for the experimental data was a Randles circuit. The Randles equivalent circuit is one of the simplest and most common circuit models of electrochemical impedance. It includes a solution resistance $R_{s}$, in series to a parallel combination of the charge transfer (corrosion) resistance $R_{c t}$, and a double layer capacitance, $C_{d l}$, respectively [35]. In this case, $R_{s}$ values can be neglected because they are too small as compared to that of $R_{c t}$ value. The equivalent circuit for the Randles cell is shown in Fig. 4.

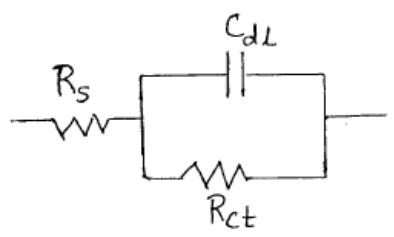

Figure 4. The equivalent circuit model used to fit the experimental results.

The FRA (frequency response analyzer) is used for impedance data analysis and the fit parameters are listed in Table 2, where, $\mathrm{R}_{\mathrm{ct}}, \mathrm{R}_{\mathrm{s}}$ and $\mathrm{C}_{\mathrm{dl}}$ are the charge transfer resistance, solution resistance and double layer capacitance, respectively.

Table 2. Impedance parameters and corresponding inhibition efficiency for the corrosion of Al-Pure in the $1.0 \mathrm{M} \mathrm{HCl}$.

\begin{tabular}{cccccc}
\hline Inhibitor & $\begin{array}{c}\text { Concentration } \\
(\% \mathrm{~V} / \mathrm{V})\end{array}$ & $\begin{array}{c}\mathrm{R}_{\mathrm{s}} \\
(\mathrm{ohm})\end{array}$ & $\begin{array}{c}\mathrm{R}_{\mathrm{ct}} \\
(\mathrm{ohm})\end{array}$ & $\begin{array}{c}\mathrm{C}_{\mathrm{dl}} \\
(\mu \mathrm{F})\end{array}$ & $\begin{array}{c}\mathrm{IE} \\
(\%)\end{array}$ \\
\hline Blank & - & 1.079 & 3.99 & 85.73 & - \\
(A) & 0.001 & 1.184 & 9.78 & 81.74 & 59.2 \\
& 0.01 & 0.949 & 14.08 & 78.96 & 71.7 \\
& 0.05 & 1.324 & 23.53 & 73.14 & 83.0 \\
& 0.10 & 1.085 & 36.55 & 68.14 & 89.1 \\
$(\mathrm{~B})$ & 0.001 & 1.121 & 11.12 & 83.65 & 64.1 \\
& 0.01 & 1.386 & 16.64 & 77.68 & 76.0 \\
& 0.05 & 1.019 & 28.19 & 74.80 & 85.8 \\
& 0.10 & 1.010 & 44.72 & 68.40 & 91.1 \\
\hline
\end{tabular}

The results show that there are increasing $R_{c t}$ values with the addition of the inhibitors when compared with those obtained without inhibitors. It should be noted that while $R_{c t}$ values increase with the addition of inhibitors, the $C_{d l}$ values decrease indicating the formation of a surface film. Thus, increase in $R_{c t}$ value and decrease in $\mathrm{C}_{\mathrm{dl}}$ values by the inhibitors are related to the increased degree of protection of Al-Pure in $1.0 \mathrm{M} \mathrm{HCl}$. The electrochemical theory shows that $\mathrm{C}_{\mathrm{dl}}$ is proportional to the corrosion rate. 


\section{Weight loss measurements}

Effect of inhibitor concentration:

To study the effect of inhibitor concentration on inhibition efficiency, weight losses were determined in $1.0 \mathrm{M} \mathrm{HCl}$ plain as well as inhibited, at $35 \pm 0.5{ }^{\circ} \mathrm{C}$ for an immersion time of 60 minutes. Table 3 shows the calculated values of inhibition efficiencies (\% IE) using the expression given in eq. (3).

Table 3. Corrosion parameters for Al-Pure in the presence and absence of different concentrations of Schiff bases obtained from weight loss measurements at $35 \pm 0.5{ }^{\circ} \mathrm{C}$ for an exposure period of 60 minutes.

\begin{tabular}{ccccc}
\hline Inhibitor & $\begin{array}{c}\text { Concentration } \\
(\% \mathrm{~V} / \mathrm{V})\end{array}$ & $\begin{array}{c}\text { Weight loss } \\
\left(\mathrm{mg} \mathrm{dm}^{-2}\right)\end{array}$ & $\begin{array}{c}\text { Surface } \\
\text { coverage }(\theta)\end{array}$ & $(\% \mathrm{IE})$ \\
\hline Blank & - & 2300 & - & - \\
(A) & 0.001 & 959 & 0.583 & 58.3 \\
& 0.01 & 642 & 0.721 & 72.1 \\
& 0.05 & 374 & 0.837 & 83.7 \\
& 0.10 & 257 & 0.888 & 88.8 \\
(B) & 0.50 & 24 & 0.990 & 99.0 \\
& 0.001 & 846 & 0.632 & 63.2 \\
& 0.01 & 569 & 0.753 & 75.3 \\
& 0.05 & 341 & 0.852 & 85.2 \\
& 0.10 & 220 & 0.904 & 90.4 \\
& 0.50 & 16 & 0.993 & 99.3 \\
\hline
\end{tabular}

Increasing the concentration of (A) and (B) inhibitors, increases the inhibition efficiency (\%IE) upto a maximum value of $>99 \%$ at $0.5 \%$ inhibitor concentration. The inhibition was found to depend on inhibitor's concentration. The inhibitory action of (A) and (B) against Al-Pure corrosion can be attributed to the adsorption of their molecules on Al-Pure surface, which limits the dissolution of the latter by blocking its corrosion sites and hence decreasing the weight loss, with increase in efficiency as the concentration increases.

\section{Adsorption isotherm}

The inhibition efficiency depends on the type and number of active sites at the metal surface, the charge density, the molecular size of the inhibitor, the metalinhibitor interaction, and the metallic complex formation [36]. The adsorption isotherm can give information on the metal-inhibitor interaction. The type of adsorption of (A) and (B) Schiff bases was elucidated from the degree of surface coverage $(\theta)$ values calculated from eq. (4) (Table-3). The values of surface coverage, $\theta$ for the inhibitors have been used to explain the best isotherms which determine the adsorption process. Attempts were made to fit $\theta$ values to various adsorption isotherms, namely Langmuir, Freundlich and Temkin. By far the best fits were obtained with Langmuir adsorption isotherm. 


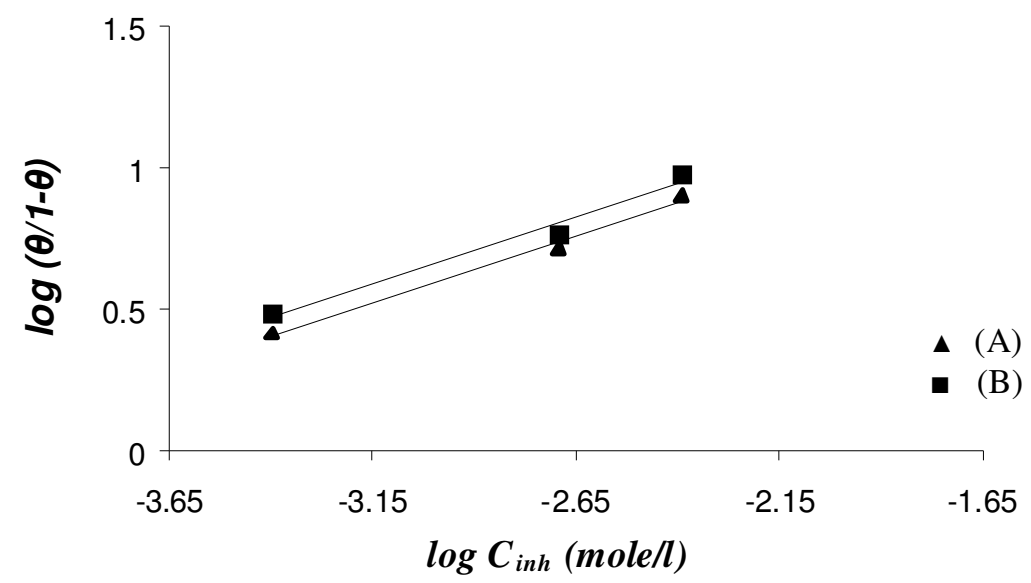

Figure 5. Langmuir isotherm for adsorption of Schiff bases on the Al-Pure metal surface.

When plots of $\log \frac{\theta}{1-\theta}$ versus $\log \mathrm{C}_{\text {inh }}$ (inhibitor concentration) were drawn (Fig. 5), straight lines were obtained (up to a certain concentration), indicating that the adsorption of the inhibitors (A) and (B) takes place following Langmuir adsorption isotherm [37].

Table 4. Effect of temperature on weight loss and inhibition efficiency for Al-Pure in 1.0 M hydrochloric acid.

\begin{tabular}{cccccc}
\hline \multirow{2}{*}{ Inhibitor } & $\begin{array}{c}\text { Concentration } \\
(\% \mathrm{~V} / \mathrm{V})\end{array}$ & \multicolumn{4}{c}{ Weight loss $\left(\mathrm{mg} \mathrm{dm}^{-2}\right)$ at temperature } \\
& - & 2300 & $45^{\circ} \mathrm{C}$ & $55^{\circ} \mathrm{C}$ & $65^{\circ} \mathrm{C}$ \\
\hline Blank & 0.5 & 24 & 68 & 5303 & 5808 \\
(A) & & $(99.0 \%)$ & $(98.5 \%)$ & 141 & 328 \\
& 0.5 & 16 & 60 & 125 & $(94.3 \%)$ \\
(B) & & $(99.3 \%)$ & $(98.6 \%)$ & $(97.6 \%)$ & $(95.1 \%)$ \\
& & & & & \\
\hline
\end{tabular}

\section{Effect of temperature}

To study the effect of temperature on the inhibition efficiency, weight losses were determined at $35^{\circ} \mathrm{C}, 45^{\circ} \mathrm{C}, 55^{\circ} \mathrm{C}$ and $65^{\circ} \mathrm{C}$ in $1.0 \mathrm{M} \mathrm{HCl}$, plain as well as inhibited. The results given in Table 4 show that the inhibition efficiencies decrease with increase in temperature.

The decrease in inhibition efficiencies with increase in temperature can be explained by desorption of the inhibitor molecules due to a higher rate of hydrogen evolution at elevated temperatures which may disturb or detach the adsorbed film from the metal surface.

\section{Thermodynamic parameters}

The thermodynamic parameters derived from the temperature data for the studied two Schiff bases are given in Table 5. 
Table 5. Thermodynamic parameters and activation energy for inhibitor adsorption for corrosion of Al-Pure in $1.0 \mathrm{M} \mathrm{HCl}$ (inhibitor concentration $0.5 \%$ ).

\begin{tabular}{cccc}
\hline Inhibitor & $\begin{array}{c}\mathrm{E}_{\mathrm{a}} \\
\left(\mathrm{kJ} \mathrm{mole}^{-1}\right)\end{array}$ & $\begin{array}{c}\mathrm{Q}_{\mathrm{ads}} \\
\left(\mathrm{kJ} \mathrm{mole}^{-1}\right)\end{array}$ & $\begin{array}{c}\Delta \mathrm{G}_{\mathrm{ads}} \\
\left(\mathrm{kJ} \mathrm{mole}^{-1}\right)\end{array}$ \\
\hline Blank & 25.9 & - & - \\
(A) & 71.5 & -50.6 & -31.4 \\
(B) & 164.4 & -57.3 & -31.8 \\
\hline
\end{tabular}

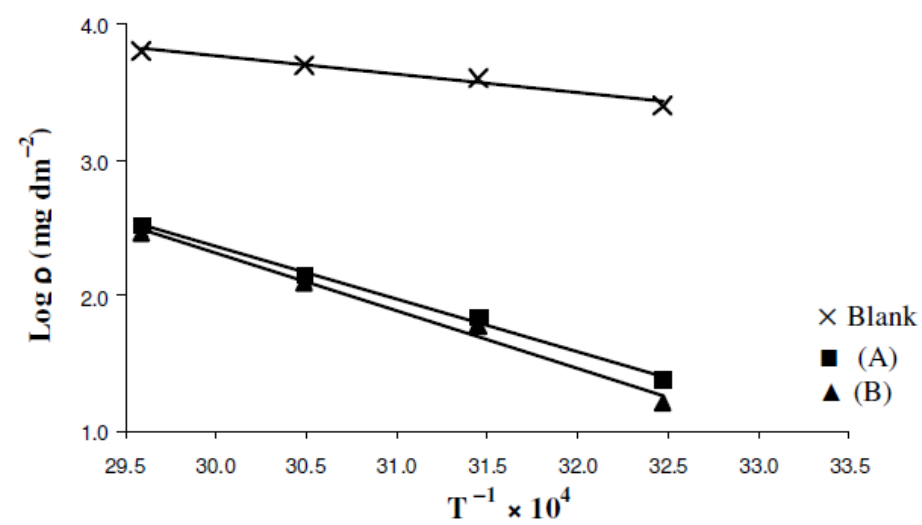

Figure 6. Plotting $\log \rho$ vs. $\mathrm{T}^{-1} \times 10^{4}$ to calculate the activation energy of the corrosion process in the presence and absence of inhibitors.

The activation parameters for the corrosion process can be evaluated from Arrhenius-type plot according to the following equation [38] :

$$
\rho=\mathrm{k} \exp \left(-E_{a} / R T\right)
$$

where, $\rho$ is the corrosion rate, $E_{a}$ is the activation energy, $T$ is the thermodynamic temperature and $\mathrm{k}$ is a constant. Plotting $\log \rho$ versus $\mathrm{T}^{-1} \times 10^{4}$ gave a straight line with slope of $-E_{a} / R$ (Fig. 6). Calculated activation energies are given in Table 5. As we can see from these data, activation energies strongly increase in the presence of inhibitors. This fact indicates that the adsorption of these inhibitors occurs through physical mechanism [39].

If it is assumed that the inhibitor is adsorbed on the metal surface in the form of a monolayer film, covering at any instant a fraction, $\theta$, of the metal surface in a uniform random manner, then the heat of adsorption, $\left(\mathrm{Q}_{\mathrm{ads}}\right)$, of the inhibitors can be calculated from the equation:

$$
\left(\mathrm{Q}_{\mathrm{ads}}\right)=2.303 \mathrm{R}\left\{\log \frac{\theta_{2}}{1-\theta_{2}}-\log \frac{\theta_{1}}{1-\theta_{1}}\right\}\left(\frac{T_{1} T_{2}}{T_{2}-T_{1}}\right)
$$

The values of the free energy of adsorption $\left(\Delta G_{a d s}\right)$ were calculated from the following equation [37]:

$$
\log C_{\text {inh }}=\log \frac{\theta}{1-\theta}-\log B
$$




$$
\text { where, } \log \mathrm{B}=-1.74-(\Delta \text { Gads } / 2.303 R T)
$$

The values of $\left(\Delta \mathrm{G}_{\mathrm{ads}}\right)$ and $\left(\mathrm{Q}_{\mathrm{ads}}\right)$ are shown in Table 5. The negative value of $\left(\Delta \mathrm{G}_{\mathrm{ads}}\right)$ ensures the spontaneity of the adsorption process and stability of the adsorbed layer on Al-Pure surface. Generally, values of $\left(\Delta \mathrm{G}_{\mathrm{ads}}\right)$ around $-20 \mathrm{~kJ}$ $\mathrm{mol}^{-1}$ or lower are consistent with physisorption, while those around $-40 \mathrm{~kJ} \mathrm{~mol}^{-1}$ or higher involve chemisorption [40]. The values of $\left(\Delta \mathrm{G}_{\mathrm{ads}}\right)$ for the two Schiff bases indicate that the molecules are physisorbed. The negative values of $\left(\mathrm{Q}_{\mathrm{ads}}\right)$ indicated that the adsorption of the used inhibitors on Al-Pure surface is exothermic.

\section{Mechanism of the inhibition}

Most organic corrosion inhibitors are compounds with at least one polar unit containing atoms of nitrogen, sulphur, oxygen and, in some cases, selenium and phosphorous. The polar unit is regarded as the reaction centre for the establishment of the adsorption process and the adsorption bond strength is determined by the electron density on the atom, acting as the reaction centre and by the polarisability of the fundamental unit [32].

Amine-type inhibitors have electron-donating ability and their action is attributed to the adsorption of the molecule on the metal surface through an unshared pair of electrons belonging to the nitrogen atom [31]. The inhibitor molecules are adsorbed chemically on the surface of the bulk metal, M, forming a charge transfer complex between the polar atom/atoms and the metal,

$$
\mathrm{M}+\mathrm{RnX} \leftrightarrow \mathrm{M}: \mathrm{XRn}
$$

Further, these inhibitors, which are in a distinct ionic form, also may get attached to the metal surface of opposite polarity through electrostatic attraction. The adsorbed layer then will block the dissolution of the metal. The size, orientation and shape of the molecule, and the electronic charge on it, will determine the degree of adsorption and hence the effectiveness of the inhibitor.

It is also possible that the compounds may form onium ions in acidic medium and move to the cathodic regions and then the adsorption will take place through the iminic nitrogen and also through the $-\mathrm{OCH}_{3}$ group $(+\mathrm{R},-\mathrm{I})$ which supplies electron density to the aromatic benzaldehydic ring and thus the delocalized $\pi$ electrons of this ring help in the adsorption of the compound with stronger bonds. It appears that the inhibitor molecules lie flat on the metal surface and cover greater areas when present in sufficient amount.

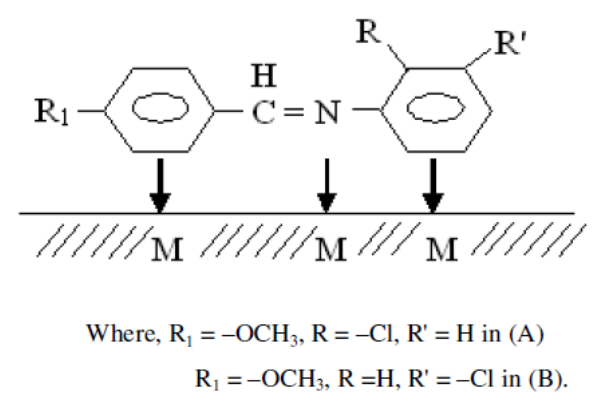




\section{Conclusions}

The inhibition of Al-Pure in $1.0 \mathrm{M} \mathrm{HCl}$ with and without different concentrations of (A) and (B) has been investigated by polarization method, EIS and weight loss method, and the main conclusions are:

(1) Two Schiff bases (A) and (B) are good inhibitors in $1.0 \mathrm{M} \mathrm{HCl}$ solution and a inhibition efficiency upto $99 \%$ was obtained. The inhibition efficiencies of (A) and $(B)$ increased with the inhibitor concentration increase.

(2) Adsorption of (A) and (B) in $1.0 \mathrm{M} \mathrm{HCl}$ solution on Al-Pure surface was found to obey the Langmuir adsorption isotherm.

(3) (A) and (B) act as mixed type inhibitors with predominant action on the cathode.

(4) The adsorption takes place due to the iminic group and $-\mathrm{OCH}_{3}$ group, therefore the inhibitive efficiency of both (A) and (B) should be almost the same.

(5) Obtained results about inhibition efficiencies from polarization study, EIS and weight loss method are in good agreement with each other.

\section{Acknowledgment}

The authors are grateful to Chemistry Department, School of Sciences, Gujarat University, Gujarat, for laboratory facility. Two of the authors, Aesha Patel and Vidhi Panchal, are also thankful to UGC-BSR for Research fellowship.

\section{References}

1. Rosliza R, Wan Nik WB, Izman S, Prawoto Y. Curr Appl Phy. 2010;10:923.

2. Zhang QB, Hua YX. Electrochim Acta. 2009;54:881.

3. Machnikova E, Whitmire KH, Hackerman N. Electrochim Acta. 2008;53:6024.

4. $\quad$ Li W, He Q, Pei C, Hou B. Electrochim Acta. 2007;52:6386.

5. Amin MA, Abd El-Rehim SS, El-Sherbini EEF, Bayoumi RS. Electrochim Acta. 2007;52:3588.

6. Addel-Gaber AM, Abd-El-Nabey BA, Sidahmed IM, El-Zayady AM, Saadawy M. Mater Chem Phys. 2006;98:291.

7. Desai MN, Desai MB, Shah CB, Desai SM. Corros Sci. 1986;26:827.

8. Abd El-Maksoud SA. Corros Sci. 2002;44:803.

9. Ajmal M, Mideen AS, Quraishi MA. Corros Sci. 1994;36:79.

10. Behpour M, Ghoreishi SM, Soltani N, Salavati-Niasari M, Hamadanian M, Gandomi A. Corros Sci. 2008;50:2172.

11. Hosseini MG, Ehteshamzadeh M, Shahrabi T. Electrochim Acta. 2007;52:3680.

12. Alvarez-Bustamante R, Negron-Silva G, Abreu-Quijano M, HerreraHernandez H, Romero-Romo M, Cuan A, Palomar-Pardave M. Electrochim Acta. 2009;54:5393.

13. Negm NA, Zaki MF. Colloid Surf A. 2008;322:97. 
14. Ehteshamzadeh M, Jafari AH, Naderia E, Hosseini MG. Mater Chem Phys. 2009;113:986.

15. Shokry H, Yuasa M, Sekine I, Issa RM, El-Baradie HY, Gomma GK. Corros Sci. 1998;40:2173.

16. Emregul KC, Hayvali M. Corros Sci. 2006;48:797.

17. Behpour M, Ghoreishi SM, Soltani N, Salavati-Niasari M. Corros Sci. 2009;51:1073.

18. Bain CD, Throughton EB, Tao YT, Evall J, Whiteside GM, Nuzzo JG. J Am Soc. 1989;111:321.

19. Emregul KC, Kurtaran R, Atakol O. Corros Sci. 2003;45:2803.

20. Gomma GK, Wahdan MH. Mater Chem Phys. 1995;39:209.

21. Hahner G, Woll C, Buck M, Grunze M. Langmuir 1993;9:955.

22. Aytac A, Ozmen U, Kabasakaloglu M. Mater Chem Phys. 2005;89:176.

23. Li SL, Chen S, Lei SB, Ma H, Yu R, Liu D. Corros Sci. 1999;41:1273.

24. Emregul KC, Atakol O. Mater Chem Phys. 2003;82:188.

25. Behpour M, Ghoreishi SM, Salavati-Niasari M, Ebrahimi B. Mater Chem Phys. 2008;107:153.

26. Yurt A, Ulutas S, Dal H, Appl Surf Sci. 2006;253:919.

27. Shah NK, Agrawal YK, Talati JD, Shah MD, Desai MN. Corros Sci. 2004;46:633.

28. Desai MN, Talati JD, Shah NK. Indian J Chem. 2003;42A:3027.

29. Talati JD, Desai MN, Shah NK. Anti-Corros Methods Mater. 2005;52:108.

30. Talati JD, Desai MN, Shah NK. Mater Chem Phys. 2005;93:54.

31. Shah MD, Panchal VA, Mudaliar GV, Shah NK. Anti-Corros Methods Mater. 2011;3:58.

32. Patel AS, Panchal VA, Shah NK. J Pure Appl Sci. 2010;18:73.

33. Shah MD, Patel AS, Mudaliar GV, Shah NK. Port Electrochim Acta. 2011;29:101.

34. Hosseini MG, Mertens SFL, Gorbani M, Arshadi MR. Mater Chem Phys. 2003;78:800.

35. Yagan A, Pekmez NO, Yildiz A. Prog Org Coat. 2006;57:314.

36. Avc G. Colloids Surf A. 2008;317:730.

37. Desai MN, Talati JD, Shah NK. Anti-Corros Methods Mater. 2008;55:27.

38. Joseph B, John S, Joseph A, Narayana B. Ind J Chem Technol. 2010;17:366.

39. Ashassi-Sorkhabi H, Shaabani B, Seifzadeh D. Appl Surf Sci. 2005;239:154.

40. Yurt A, Bereket G, Kivrak A, Balaban A, Erk B. J Appl Electrochem. 2005;35:1025. 